\title{
Clarification of data for a meta-analysis: p53 codon 72 polymorphism and prostate cancer risk
}

\author{
Y.-Y. Mi, L.-J. Zhu, X.-M. You and S. Wu \\ Department of Urology, Third Affiliated Hospital of Nantong University, \\ Wuxi, China \\ Corresponding author: L.-J. Zhu \\ E-mail: zhulijiemeta@hotmail.com
}

Genet. Mol. Res. 11 (3): 1958-1959 (2012)

Received May 10, 2012

Accepted June 27, 2012

Published July 19, 2012

DOI http://dx.doi.org/10.4238/2012.July.19.15

Dear Editor,

Recently, we read with great interest the article "Meta-analysis demonstrates no association between $\mathrm{p} 53$ codon 72 polymorphism and prostate cancer risk" published in November 2011 in "Genetics and Molecular Research" (Li et al., 2011). Li et al. (2011) performed a meta-analysis to make an estimation of the association between codon 72 polymorphism of the $\mathrm{p} 53$ gene and prostate cancer risk. They concluded that there is no association between $\mathrm{p} 53$ codon 72 polymorphism and prostate cancer risk both in Caucasian and Asian populations.

Nevertheless, some methodological issues need to be addressed concerning the metaanalysis by Li et al. (2011). Importantly, using the same search strategy and end-of-search date as those of Li et al. (2011), we have located four relevant studies in Pubmed database with a total of 544 prostate cancer patients and 1005 controls (Wu et al., 1995; Hirata et al., 2007, 2009; Xu et al., 2010) (Table 1), which were not included in the meta-analysis even though they were consistent with the search criteria. Among them, two articles (Hirata et al., 2007, 2009) had duplicate data of cases and controls, so we selected the most complete and larger study (Hirata et al., 2007). Finally, three newly additional studies should be included. 
Table 1. Characteristics of the additional four studies and distribution of $\mathrm{p} 53$ codon 72 polymorphisms between prostate cancer and control individuals in the new meta-analysis.

\begin{tabular}{|c|c|c|c|c|c|c|c|c|c|c|}
\hline \multirow[t]{2}{*}{ First author (Year) } & \multirow[t]{2}{*}{ Country } & \multirow[t]{2}{*}{ Ethnicity } & \multirow[t]{2}{*}{ Case } & \multirow[t]{2}{*}{ Control } & \multicolumn{3}{|c|}{ Case } & \multicolumn{3}{|c|}{ Control } \\
\hline & & & & & Pro/Pro & Pro/Arg & Arg/Arg & Pro/Pro & Pro/Arg & Arg/Arg \\
\hline Hirata (2007) & Japan & Asian & 167 & 167 & 22 & 89 & 56 & 26 & 80 & 61 \\
\hline Wu (1995) & Japan & Asian & 28 & 403 & 2 & 14 & 12 & 44 & 189 & 170 \\
\hline $\mathrm{Xu}(2010)$ & China & Asian & 209 & 268 & 41 & 129 & 39 & 86 & 140 & 42 \\
\hline Hirata (2009) & Japan & Asian & 140 & 167 & 20 & 75 & 45 & 26 & 80 & 61 \\
\hline
\end{tabular}

Secondly, one recent study by Ricks-Santi et al. (2010) reported the relationship between p53 Pro72Arg polymorphism and prostate cancer in men of African descent. However, $\mathrm{Li}$ et al. (2011) considered the race as Caucasian populations not Africans.

Moreover, in the statistical analysis section, the authors gave a $\mathrm{P}$ value $<0.10$ for the Q-statistic that indicated heterogeneity among the studies. Actually, a P value $<0.05$ rather than $<0.10$ for the Q-statistic indicates heterogeneity across studies (Xu et al., 2012).

Taking into account the aforementioned methodological considerations, we put all studies into a new meta-analysis, including three large eligible studies, and we observed that codon 72 polymorphism of the p53 gene was also not significantly correlated with prostate risk: Pro-allele $v s$ Arg-allele $\left(\mathrm{OR}=1.01,95 \% \mathrm{CI}=0.85-1.20, \mathrm{P}_{\text {heterogeneity }}=0.017, \mathrm{P}=0.936, \mathrm{I}^{2}\right.$ $=55.2 \%), \operatorname{Pro} / \operatorname{Pro} v s \operatorname{Arg} / \operatorname{Arg}\left(\mathrm{OR}=1.01,95 \% \mathrm{CI}=0.64-1.60, \mathrm{P}_{\text {heterogeneity }}=0.002, \mathrm{P}=0.953, \mathrm{I}^{2}\right.$ $=65.1 \%), \operatorname{Pro} / \operatorname{Arg} v s \operatorname{Arg} / \operatorname{Arg}\left(\mathrm{OR}=1.19,95 \% \mathrm{CI}=0.91-1.56, \mathrm{P}_{\text {heterogeneity }}=0.030, \mathrm{P}=0.207\right.$, $\left.\mathrm{I}^{2}=51.2 \%\right), \operatorname{Pro} / \operatorname{Pro}+\operatorname{Pro} / \operatorname{Arg} v s \operatorname{Arg} / \operatorname{Arg}\left(\mathrm{OR}=1.12,95 \% \mathrm{CI}=0.88-1.44, \mathrm{P}_{\text {heterogeneity }}=0.045\right.$, $\left.\mathrm{P}=0.357, \mathrm{I}^{2}=47.8 \%\right)$, and Pro/Pro vs Pro/Arg $+\operatorname{Arg} / \operatorname{Arg}(\mathrm{OR}=0.88,95 \% \mathrm{CI}=0.60-1.29$, $\left.\mathrm{P}_{\text {heterogeneity }}=0.003, \mathrm{P}=0.513, \mathrm{I}^{2}=64.3 \%\right)$. Similar associations were also detected in subgroups by race and source of controls.

In conclusion, the results of the study by Li et al. (2011) should be interpreted with caution. To reach a definitive conclusion, further studies based on a larger sample size are still needed to assess the association of p53 gene codon 72 polymorphisms and serum expression with prostate cancer risk, especially in African and Caucasian populations. We believe that our remarks will contribute to more accurate elaboration of the results presented by Li et al. (2011).

\section{REFERENCES}

Hirata H, Hinoda Y, Kikuno N, Kawamoto K, et al. (2007). CXCL12 G801A polymorphism is a risk factor for sporadic prostate cancer susceptibility. Clin. Cancer Res. 13: 5056-5062.

Hirata H, Hinoda Y, Kikuno N, Suehiro Y, et al. (2009). Bcl2 -938C/A polymorphism carries increased risk of biochemical recurrence after radical prostatectomy. J. Urol. 181: 1907-1912.

Li MS, Liu JL, Wu Y, Wang P, et al. (2011). Meta-analysis demonstrates no association between p53 codon 72 polymorphism and prostate cancer risk. Genet. Mol. Res. 10: 2924-2933.

Ricks-Santi L, Mason T, Apprey V, Ahaghotu C, et al. (2010). p53 Pro72Arg polymorphism and prostate cancer in men of African descent. Prostate 70: 1739-1745.

Wu WJ, Kakehi Y, Habuchi T, Kinoshita H, et al. (1995). Allelic frequency of p53 gene codon 72 polymorphism in urologic cancers. Jpn. J. Cancer Res. 86: 730-736.

Xu B, Xu Z, Cheng G, Min ZC, et al. (2010). Association between polymorphisms of TP53 and MDM2 and prostate cancer risk in southern Chinese. Cancer Genet. Cytogenet. 202: 76-81.

Xu B, Tong N, Chen SQ, Yang Y, et al. (2012). Contribution of HOGG1 Ser ${ }^{326}$ Cys polymorphism to the development of prostate cancer in smokers: meta-analysis of 2779 cases and 3484 controls. PLoS One 7: e30309. 